\title{
Analgesic effectiveness of the association of transcutaneous electrical nerve stimulation and cryotherapy for chronic low back pain*
}

\section{Eficácia analgésica da associação da eletroestimulação nervosa transcutânea e criote- rapia na lombalgia crônica}

\author{
Eliziete Almeida de Abreuํㄹ , Jean Douglas Moura dos Santos², Patrícia Lima Ventura ${ }^{3}$ \\ * Received from the Physical Therapy Clinic FISIOCLIN. Teresina, PI.
}

\section{SUMMARY}

BACKGROUND AND OBJECTIVES: Transcutaneous electrical nerve stimulation (TENS) and cryotherapy are physical therapy resources individually used, since there is the possibility of interaction between TENS and cryotherapy if they are associated. This study aimed at evaluating the analgesic effectiveness of the association or not of TENS and cryotherapy to relieve chronic low back pain.

METHOD: Clinical trial involving six chronic low back pain patients distributed in three groups: cryotherapy, TENS, and the association of both techniques. Analgesia was induced for 20 minutes during 5 days, with one session per day. All patients were submitted to conventional kinesiotherapy with ischiotibial, lumbar square and iliopsoas elongation, aiming at increasing adherence to treatment. Cryotherapy was applied with crushed ice bag and TENS was in burst with Physiotonus TENS/FES 3050 equipment of the BIOSET brand, with pulse trains of $2 \mathrm{~Hz}$, individual pulse frequencies of $100 \mathrm{~Hz}$ and pulse duration of 150 $\mu \mathrm{s}$. Pain intensity was evaluated by the visual analog scale before and after each session.

1. Physical Therapist; Specialist in Physical Therapy Applied to Orthopedics and Traumatology by Differential Integral University. Teresina, PI, Brazil.

2. Physical Therapist; Master in Bioengineering by the University of Paraíba Valley. São José dos Campos, SP, Brazil.

3. Physical Therapist; Master in Bioengineering by the University of Paraíba Valley. São José dos Campos, SP, Brazil.

Correspondence to:

Patrícia Lima Ventura

Rua Coelho de Resende 692 Centro-Sul

64001-370 Teresina, PI.

E-mail: vlpatricia@hotmail.com
RESULTS: With regard to pain intensity in the cryotherapy group, initial and final medians were 5.5 and 4 , respectively. For the TENS and TENS associated to cryotherapy groups they were 5 and 3 , respectively. With regard to pain relief, $100 \%$ have referred good relief in the TENS group; in cryotherapy and TENS associated to cryotherapy groups $50 \%$ have referred good relief and $50 \%$ very good relief.

CONCLUSION: Although the combined therapy has caused no significant improvement as compared to isolated therapies the three analgesic modalities used in this study were effective to relieve chronic low back pain. Satisfaction was higher in the cryotherapy group as compared to the TENS group.

Keywords: Cryotherapy, Low back pain, Transcutaneous electrical nerve stimulation.

\section{RESUMO}

JUSTIFICATIVA E OBJETIVOS: A eletroestimulação nervosa transcutânea (TENS) e a crioterapia são recursos fisioterapêuticos aplicados isoladamente, uma vez que existe a possibilidade de interação entre a TENS e a crioterapia caso sejam utilizadas associadas. O objetivo desse estudo foi avaliar a efetividade analgésica da associação TENS e crioterapia isoladas e associadas no alívio da lombalgia crônica.

MÉTODO: Trata-se de ensaio clínico envolvendo 6 pacientes com dor lombar crônica, divididas em 3 grupos: crioterapia, TENS, e associação crioterapia e TENS. A técnica analgésica foi aplicada pelo tempo de 20 minutos, durante 5 dias, com 1 sessão por dia. Todas as pacientes foram submetidas à cinesioterapia convencional com alongamento de isquiostibiais, quadrado lombar e iliopsoas, com o objetivo de au- 
mentar a aderência ao tratamento. A crioterapia foi feita com bolsa de gelo moído, e a modalidade de TENS foi a burst, com o aparelho Physiotonus TENS/ FES 3050, da marca BIOSET, com trens de pulsos de $2 \mathrm{~Hz}$, frequência individual de pulsos de $100 \mathrm{~Hz}$ e duração de pulso de $150 \mu \mathrm{s}$. A intensidade da dor foi avaliada pela escala analógica visual antes e após a realização de cada sessão.

RESULTADOS: Quanto a intensidade da dor, no grupo crioterapia, as medianas dos escores iniciais e finais foram 5,5 e 4, respectivamente, e nos grupos TENS e TENS associado à crioterapia as medianas foram 5 e 3, respectivamente. Quanto ao grau de alívio, 100\% referiram alívio bom no grupo TENS, e nos grupos crioterapia e TENS associado à crioterapia $50 \%$ referiram alívio bom e 50\% alívio muito bom.

CONCLUSÃO: Apesar da terapia combinada não ter apresentado nenhuma melhora significativa em relação às modalidades de terapias isoladas, as três modalidades analgésicas utilizadas neste estudo foram eficazes em aliviar a dor lombar crônica das pacientes e nos grupos em que foi utilizado a crioterapia o grau de satisfação das pacientes foi maior do que as do grupo em que foi usada apenas a TENS.

Descritores: Crioterapia, Eletroestimulação nervosa transcutânea, Lombalgia.

\section{INTRODUCTION}

Low back pain is a rather common problem affecting more people than any other affection, being the most common cause for medical visits, only loosing to common cold. The direct or indirect costs it generates exceed those of any other disease, including coronary diseases $^{1}$. Between $65 \%$ and $80 \%$ of the world population develop back pain at some point of their lives, however most cases have spontaneous resolution. Anatomic low back pain causes are several, including muscle stress, ligament changes, fractures, intervertebral disc rupture, muscle stretching and tendinites ${ }^{2}$ Two treatments are used by the physical therapy practice to relief lumbar pain: cryotherapy, which removes body heat decreasing tissue temperature ${ }^{3}$, and transcutaneous electrical nerve stimulation (TENS), which consists in the generation of electrical impulses through the skin by electrodes, aiming at preventing the nociceptive information transmission to the brain ${ }^{4}$.
Cryotherapy should be applied for 10 to 30 minutes, one or several times a day, and should be avoided in anesthetized areas, in individuals with consciousness and cognition deficit, intolerance to cold, Reynaud's disease, cryoglobulinemia and circulatory failure, among others ${ }^{5}$.

TENS may also be applied for 10 to 30 minutes, one or several times a day, being counterindicated to those with pacemakers, with cardiac disease, with pain without defined etiology, in epileptic patients without medical follow-up and in pregnant women during the first quarter.

It should not be used on carotid areas, on the mouth, ruptured skin, on the abdomen during gestation and on eyelids ${ }^{6}$.

Both analgesic modalities sometimes are individually applied since there is a major academic discussion about the possible cancellation of TENS effect by cryotherapy if they are associated.

This study aimed at evaluating the effectiveness of TENScryotherapy association to relief chronic low back pain as compared to isolated applications of both techniques.

\section{METHOD}

After the approval of the Research Ethics Committee, Differential Integral University (Process n. 487), and this clinical trial was carried out involving 6 female patients with chronic low back pain, in a private clinic of the city of Teresina, PI, from January to March 2009. Inclusion criteria were patients aged between 50 and 60 years, with complete elementary school and diagnosis of spondyloarthritis confirmed by complementary exams and with pain intensity equal to or above 5 by the visual analog scale (VAS). Exclusion criteria were patients under analgesic or anti-inflammatory drugs and counterindications for the use of TENS or cryotherapy. Each patient answered to the Owestry questionnaire, specific to evaluate low back pain in terms of interfering with daily life activities (DLA), before and after the research.

Participants were divided in three groups: cryotherapy, TENS, and TENS-cryotherapy association. Analgesic technique was applied for 20 minutes during 5 days, with 1 session per day. All patients were submitted to conventional kinesiotherapy with ischiotibial, lumbar square and iliopsoas elongation, aiming at improving adhesion to treatment, since it could be 
considered inconsistent with 20 minutes of cryotherapy or TENS per day.

Crushed ice bag, exactly positioned on the pain site, was used for cryotherapy. TENS modality of choice was burst, placing a pair of silicone rubber electrodes impregnated with carbon on the lumbar paravertebral region. The equipment used was Physiotonus TENS/ FES 3050 model of the BIOSET brand, programmed with pulse trains of $2 \mathrm{~Hz}$, individual pulse frequencies of $100 \mathrm{~Hz}$ and pulse duration of $150 \mu$ s. Intensity was individually adjusted until the moment when there was comfortable tingling sensation associated to rhythmic muscle contracture in the region where the electrodes were applied. In the association of both modalities, the equipment was turned on, TENS parameters were adjusted similarly to the individual application, and the ice bag was immediately positioned on the painful region. After the application of each technique conventional bilateral kinesiotherapy was performed, dedicating 5 repetitions lasting 15 minutes for each type of elongation. Pain intensity was evaluated with VAS before and after each session; time for beginning of pain relief; analgesic duration as well as its quality by using the terms very good relief, good relief, moderate relief, no relief, to check the level of compatibility with pain intensity information by VAS. Statistical analysis was performed with Excel XP and Bioestat 5.0 programs. Kurskal-Wallis test was used to compare pain levels among patients before and after each intervention, to compare pain levels among groups and to compare pain decrease levels among groups. Wilcoxon's test was used to compare pain levels within each group before and after each intervention. Significance level was 0.05 .

\section{RESULTS}

Mean age was 51.5 years in the cryotherapy group, 49 years in the TENS group and 50.5 years in the TENScryotherapy association group. Mean low back pain duration was 16 months for the cryotherapy group, 10.5 months for the TENS group and 13 months for the TENS-cryotherapy association group. Initial VAS score median was 5.5 for the cryotherapy group, 5 for the TENS group and 5 for the TENS-cryotherapy association group, while final score median was 4 for the cryotherapy group, 3 for the TENS groups and 3 for the TENS-cryotherapy group (Table 1).

Significance levels corresponding to the differences between medians of initial and final VAS scores were 0.003 for the cryotherapy group, 0.007 for the TENS group and 0.004 for the TENS-cryotherapy association group (Table 2)

With regard to beginning of pain relief, it was in average 5 minutes after application for the cryotherapy and the TENS-cryotherapy association groups. For the TENS group it was 10 minutes after applications. Mean analgesia duration was 1 hour for all groups. With regard to pain relief, $100 \%$ of TENS group patients have referred good relief. In the cryotherapy and TENS-cryotherapy association groups, 50\% have referred good relief and 50\% very good relief. This analysis was performed at the end of the fifth session to check the level of patients' satisfaction with the analgesic modalities.

In comparing the answers of Owestry questionnaire applied at the first and fifth sessions, the cryotherapy group showed significant changes in 7 items (pain intensity, standing up, sitting down, standing, sleeping, sexual life and social life). As to other questionnaire

Table 2 - Mean and median of labor duration, in hours

\begin{tabular}{lcc}
\hline Groups & Mean & Median \\
\hline TENS & 12.5 & 11.1 \\
Control & 13.9 & 12.8 \\
\hline
\end{tabular}

Table 1 - Initial* (iVAS) and final** (fVAS) VAS median by group

\begin{tabular}{|c|c|c|c|c|}
\hline Groups & VAS scores & $\mathrm{N}^{\mathrm{o}}$ & $\%$ & Median \\
\hline \multirow[t]{2}{*}{ Cryotherapy } & iVAS & 2 & 33.3 & 5.5 \\
\hline & fVAS & 2 & 33.3 & 4 \\
\hline \multirow[t]{2}{*}{ TENS } & iVAS & 2 & 33.3 & 5 \\
\hline & fVAS & 2 & 33.3 & 3 \\
\hline \multirow[t]{2}{*}{ TENS-cryotherapy association } & iVAS & 2 & 33.3 & 5 \\
\hline & fVAS & 2 & 33.3 & 3 \\
\hline
\end{tabular}


items (personal care, walking and traveling), answers coincided at the first and fifth sessions.

The TENS group showed positive differences in 5 items of the questionnaire (pain intensity, personal care, sitting, standing and sleeping). With regard to other questionnaire items (standing up, walking, sexual life, social life and traveling) the answers coincided at the first and fifth sessions.

In the TENS-cryotherapy association group, differences were significant in 8 items (pain intensity, personal care, standing up, walking, sitting, standing, sleeping and sexual life). The answers of "social life" and "traveling" items were coincident for the first and last session.

\section{DISCUSSION}

Cryotherapy and TENS are techniques used to treat low back pain because both induce analgesia. Cryotherapy and TENS isolated effects have their efficacy scientifically proven to control pain, however TENS and cryotherapy have been simultaneously used because it is believed that there is potentiation of the analgesic effect and, as a consequence, a more effective response to improve pain.

Cold applications, below $10^{\circ} \mathrm{C}$, relieve pain because they decrease the number of painful impulses sent to the brain in addition to slowing them down. A 20-minute cold application may decrease in up to $29.4 \%$ the transmission of painful impulses and the effect may remain for approximately $30 \mathrm{~min}$ utes after its removal. Temperature decrease acts as another sensory stimulation in the pain behavior mechanism, and since cold stimulations are very intensive, they may lead to endorphins and encephalins release ${ }^{7}$.

In inflammatory processes, cold decreases hyperemia and edema due to its vasoconstrictor action. In the muscle, it decreases triggering speed of I A fibers of the muscle spindle, decreasing spasm ${ }^{8}$.

Different theories were proposed to explain TENS action mechanism, however, the most widely accepted it the Theory of Pain Floodgate Control, according to which nociceptive information competes with nervous fibers transmitting artificial electric stimulations generated by TENS to upper centers, modulating painful information in segmental and subsegmental areas of the central nervous system ${ }^{9,10}$. A different theory proposed to explain TENS action mechanism is through the activation of inhibitory pain pathways, of periaquedutal and raphe nucleus gray matter, which originate in the brain and descend to the spinal cord through brain stem, releasing endogenous opioids ${ }^{4}$.

Analysis of results has shown no statistically significant difference among groups with regard to initial VAS scores, that is, there has been equivalence of initial pain intensity among participants of the study. With regard to final VAS scores there has also been no statistically significant difference of median values among groups, showing that no analgesic technique was better than the others. However the differences between initial and final VAS scores in each group were statistically significant, showing that all modalities were effective to relieve pain.

With regard to time elapsed for pain relief, the analgesic response provided by cryotherapy and by TENS-cryotherapy association was faster as compared to TENS alone, probably due to cryotherapy effects.

Our study results are partially in agreement with another study carried out with 12 female patients who also were divided in 3 groups similar to our study, however they were submitted to two sessions per week, for one month, in a total of 8 sessions. In patients treated with TENS and TENScryotherapy association, pain referred through VAS presented significant improvement at final evaluation as compared to initial evaluation of the same group $(\mathrm{p}<0.05)$.

The group receiving cryotherapy alone did not show significant pain relief at final evaluation as compared to initial evaluation ( $p>0.05)$. However, when comparing pain at final evaluation among groups, there has been no significant difference in the improvement obtained with the protocols used $(\mathrm{p}>0.05)^{10}$. So, such results are in agreement with our study, contrasting only with regard to the cryotherapy group, where our study has evidenced significant pain relief, maybe due to the difference in methodology to induce analgesic technique, which in our study was during 5 days, with 1 session per day, and in the other study it was 2 sessions per week during 4 weeks.

An experimental study was carried out with rats, aim- 
ing at evaluating electrical femoral nerve activity (FNA) after the isolated and associated application of TENS and cryotherapy. Nine rats were studied with the application of $50 \mathrm{~Hz}$ TENS and intensity of 10 $\mathrm{mA}$ for 5 minutes, isolated cryotherapy and TENScryotherapy association for 10 minutes. The study has shown that the association of both techniques has significantly attenuated the effects produced by isolated TENS on FNA of rats ${ }^{11}$.

The reason why it is believed that TENS could inhibit cryotherapy action and vice-versa, thus not recommending their joint use, is based on the knowledge that pain is transmitted by the lateral spinothalamic bundle, which is also the way to transmit temperature, which would justify the efficacy of cryotherapy to relieve pain, however TENS acts in the touch transmission way, which is the anterior spinothalamic bundle. However, both become a single pathway at the level of the pons, forming the spinal lemniscus, which goes to the thalamus ${ }^{4,10}$.

Results obtained by this study related to functional incapacities associated to low back pain using the Owestry Disability Index (ODI), have shown that cryotherapy and TENS-cryotherapy association groups suffered less interference of pain when performing daily life activities as compared to the TENS group. ODI, also known as Owestry Low Back pain Disability Questionnaire, is an extremely important tool created to give the physician information on how low back pain affects the ability of patients to manage their daily lives ${ }^{12}$. These results probably justify the higher level of satisfaction of patients of those groups. Although the combined therapy has not represented any significant improvement as compared to isolated modalities, the three analgesic modalities used in this study were effective to relieve chronic low back pain and in the group where cryotherapy was used, the level of patients' satisfaction was higher that in the group using TENS alone.

Our results suggest that there is no interaction between TENS and cryotherapy when associated to treat chronic low back pain, however it is necessary to stress that the number of studied patients was very small, which may interfere with results. Other studies are needed to confirm that TENS does not increase or decrease the efficacy of cryotherapy for chronic low back pain.

\section{CONCLUSION}

Although the combined therapy has not presented any significant improvement as compared to isolated therapeutic modalities, the three analgesic modalities used in this study were effective to relieve chronic low back pain, and in the cryotherapy group patients satisfaction was higher as compared to TENS alone.

\section{REFERENCES}

1. Cárdenas RU. Dolor lumbar: una aproximación general basada en la evidencia. Univ Med 2008;49(4):509-20.

2. Santos KGLL, Silva MAG, Pereira JS et. al. Prevalência de lombalgia em praticantes de exercício contraresistência. Rev Fisio Br 2004;5(1):37-44.

3. Leventhal LC, Bianchi RC, de Oliveira SM. Clinical Trial comparing three trypes of cryotherapy in nonpregnant women. Rev Esc Enferm USP 2010;44(2):339-45.

4. Tribioli RA. Análise crítica atual sobre a TENS envolvendo parâmetros de estimulação para o controle da dor. Dissertação (Mestrado em Bioengenharia) Universidade de São Paulo, Ribeirão Preto, 2003.

5. Yeng LT, Stump P, Kaziyama HHS et. al. Medicina física e reabilitação em doentes com dor crônica. Rev Med 2001;80(PT 2):245-55.

6. Ferreira CHJ, Beleza ACS. Abordagem fisioterapêutica na dor pós-operatória: a eletroestimulação nervosa transcutânea. Rev Col Bras 2007;34(2):127-30.

7. Araújo IM, Leitão TC, Ventura PL. Estudo comparativo da eficiência do calor e frio no tratamento da dismenorreia primária. Rev Dor 2010;11(3):218-21.

8. Marques AP, Kondo A. A fisioterapia na osteoartrose:uma revisão de literatura. Rev Bras Reumatol 1998;38(2):83-90.

9. Radhakrishnan R, Sluka KA. Deep tissue afferents, but not cutaneous afferents, mediate transcutaneous electrical nerve stimulation-induced antihyperalgesia. J Pain 2005;6(10):673-80.

10. Sluka KA, Vance CGT, Lisi TL. High-frequency, but not low-frequency, transcutaneous electrical nerve stimulation reduces aspartate and glutamate release in the spinal cord dorsal horn. J Neurochem. 2005a;95:(6)1794-801.

11. Ribeiro RS, Monteiro TV, Abdon APV. Estudo 28 
do efeito da utilização simultânea da crioterapia e do TENS nos pacientes portadores de lombalgia. Rev Terapia Manual 2006;4(16):82-7.

12. Santuzzi CH, Gonçalves WLS, Rocha SS et. al. Efeitos da crioterapia, estimulação elétrica transcutânea e da sua associação na atividade elétrica do nervo fem- oral em ratos. Rev Bras Fisioter 2008;12(6):441-6. 13. Fairbank JC, Pynsent PB. The Oswestry Disability Index. Spine 2000;25(22):2940-52.

Presented in October 22, de 2010.

Accepted for publication in February 26, 2011. 